\title{
АНАЛІЗ СИСТЕМНОЇ ДИНАМІКИ ЕПІДМЕМІЧНОГО ПРОЦЕСУ ВІЛ-ІНФЕКЦІї / СНІДУ В УКРАЇНІ
}

\author{
С. О. Соловйов ${ }^{1,2}$, І. В. Дзюблик ${ }^{1}$, О. В. Ковалюк ${ }^{1}$, \\ О. С. Олефрір ${ }^{2}$, В. В. Мальчиков ${ }^{2}$, А. А. Симчук ${ }^{3}$ \\ ${ }^{1}$ Національний університет охорони здоров'я України імені П. Л. Шупика \\ ${ }^{2}$ Національний технічний університет України «Київський політехнічний інститут \\ імені Ігоря Сікорського» \\ зУніверситетська лікарня Преображення Господнього, Республіка Польща
}

\begin{abstract}
З використанням наявних статистичних даних про щомісячну захворюваність та поширеність ВІЛ-інфрекції / СНІДу в Україні, статистичних демографрічних даних українського населення побудовано модель, що описує три підгрупи українського населення в динаміці з огляду на епідемічний процес захворювання. Аналіз моделі показав, що ключові параметри епідемічного процесу ВІЛ-інфрекції / СНІДу зменшуються з часом. Побудовану динамічну модель досліджено на предмет рівноважної стійкості. Показано, що невелике збурення динамічної системи (зміна чисельності населення, запровадження стратегій профрілактики тощо) може призвести до зміщення її рівноваги та прихильності до нової точки рівноваги. Факт спадних ключових параметрів епідемічного процесу ВІЛ-інфекції / СНІДу свідчить про ефективність існуючих стратегій проорілактики, таких як тестування та антиретровірусна терапія.
\end{abstract}

Ключові слова: профрілактика ВІЛ-інфекції, динамічна модель, рівноважна стабільність.

\section{ANALYSIS OF HIVIAIDS SYSTEM DYNAMICS IN UKRAINE}

\author{
S. O. Soloviov ${ }^{1,2}$ I. V. Dziublyk1, O. V. Kovaliuk ${ }^{1}$, \\ O. S. Olephir², V. V. Malchykov², A. A. Symchuk ${ }^{3}$ \\ ${ }^{1}$ Shupyk National Healthcare University of Ukraine \\ ${ }^{2}$ National Technical University of Ukraine «Igor Sikorsky Kyiv polytechnic institute» \\ ${ }^{3}$ University Hospital of Lord's Transfiguration, Poland
}

\begin{abstract}
Background. Using the available statistics on the monthly incidence and prevalence of HIV / AIDS in Ukraine and statistical demographic data of the Ukrainian population, a model was built that describes three subgroups of the Ukrainian population in dynamics with respect to the epidemic process of the disease. The aim of this study is to use an SD approach in the modeling of the HIVIAIDS epidemic in Ukraine to estimate its features and trends.

Materials and methods. Used open statistical data on the monthly incidence and prevalence of HIV / AIDS in Ukraine, as well as statistical data on the population of Ukraine.

Results. The analysis of the model showed that the key parameters of the HIV / AIDS epidemic process decrease over time. The developed dynamic model was investigated for equilibrium stability. It was shown that a small disturbance of the dynamic system (population change, introduction of prevention strategies, etc.) can lead to a shift in its balance to a new equilibrium point. The fact that the key parameters of the HIV / AIDS epidemic process are declining indicates the effectiveness of existing prevention strategies, such as testing and antiretroviral therapy.

Conclusions. In the field of HIV prevention, analytic models become necessary for analysis of recent epidemiological data, so simulation of impact of dynamic behavior of HIV prevalence in recent population. In our research, we proposed to consider Ukrainian population as a dynamic system in the context of HIV epidemics. Such dynamic system was divided into three compartments, reflecting susceptible, HIV-infected and AIDS population
\end{abstract}

Key words: HIV prevention, dynamical models, equilibrium stability. 


\title{
АНАЛИЗ СИСТЕМНОЙ ДИНАМИКИ ЭПИДЕМИЧЕСКОГО ПРОЦЕССА ВИЧ- ИНФЕКЦИИ / СПИДА В УКРАИНЕ
}

\author{
С. А. Соловьёв ${ }^{1,2}$, И. В. Дзюблик', Е. В. Ковалюк', \\ А. С. Олефир 2 , В. В. Мальчиков ${ }^{2}$, А. А. Симчук ${ }^{3}$ \\ ${ }^{1}$ Национальный университет здравоохранения Украины имени П. Л. Шупика \\ ${ }^{2}$ Национальний технический университет Украины «Киевский политехнический институт \\ имени Игоря Сикорского» \\ зуниверситетская больница Преображения Господнего, Республика Польша
}

\begin{abstract}
С использованием имеющихся статистических данных по ежемесячной заболеваемости и распространенности Вичинфекции / СПИДа в Украине и демографрических данных украинского населения была построена модель, которая описывает три подгруппы украинского населения в динамике с учетом эпидемического процесса заболевания. Анализ модели показал, что ключевые параметры эпидемического процесса ВИЧ-инсрекции / СПИДа уменьшаются со временем. Построенная динамическая модель была исследована на предмет равновесной устойчивости. Показано, что небольшое возмущение динамической системы (изменение численности населения, внедрение стратегий просрилактики и т.п.) может привести к смещению ее равновесия к новой точки равновесия. Факт нисходящих ключевых параметров эпидемического процесса ВИЧ-инфекции / СПИДа свидетельствует об эффективности существующих стратегий профилактики, таких как тестирование и антиретровирусная терапия.
\end{abstract}

Ключевые слова: профилактика ВИЧ, динамические модели, стабильность равновесия.

Introduction. Recent advances in HIV prevention and treatment have decreased the number of new HIV infections in many regions of the world [1, 2]. However, despite these advances, the HIV epidemic continues to grow geographic locations where evidence based prevention and treatment are not readily accessible to those individuals who need them most. In particular, the HIV epidemics in Eastern Europe and Central Asia have been rapidly growing over the past decade [3]. Ukraine has been experiencing one of the fastest growing HIV epidemics in the world [4]. Thus, there is an important need to implement evidenced based HIV prevention and treatment among high-risk populations in Ukraine.
System dynamics (SD) modeling is a research methodology explicitly intended to promote in-depth learning about dynamically complex problems [5, 6]. SD simulation is now used routinely throughout the natural and social sciences, hailed as a «third branch of science», standing alongside theory and experiment as a unique and vital method to advance human knowledge. SD models in general «involve set of simultaneous nonlinear differential equations and these relationships are notoriously difficult to handle mathematically» [7, 8]. Specifically, SD has been applied directly to modeling of the HIV epidemic in numerous settings $[9,10]$. The aim of this study is to use an SD approach in the modeling of the HIV/AIDS epidemic in Ukraine to estimate its features and trends.

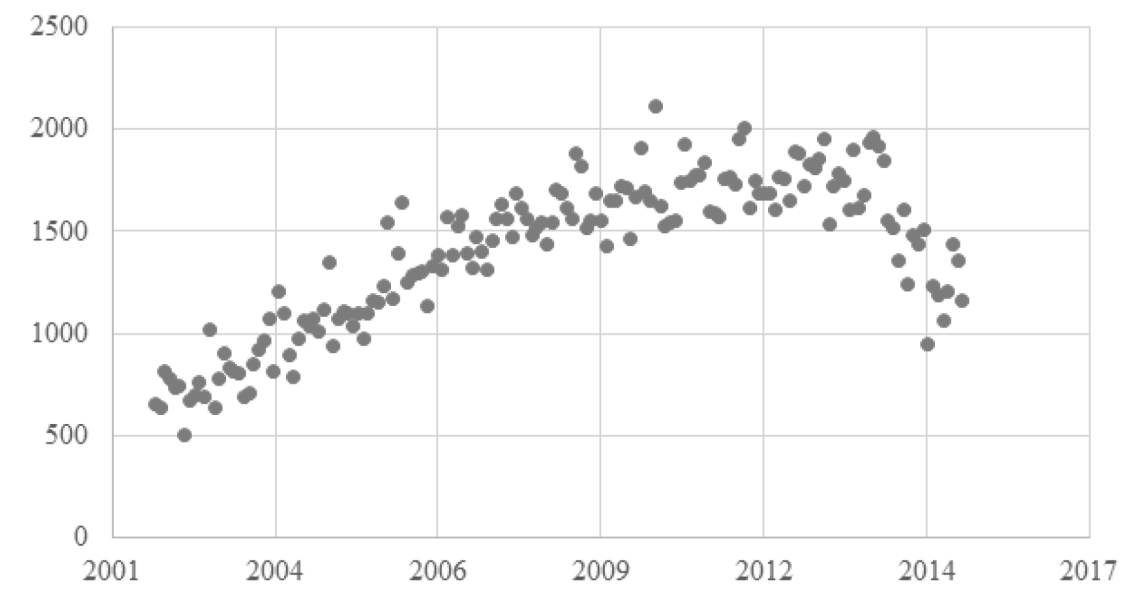

Fig. 1. The number of new HIV infections 


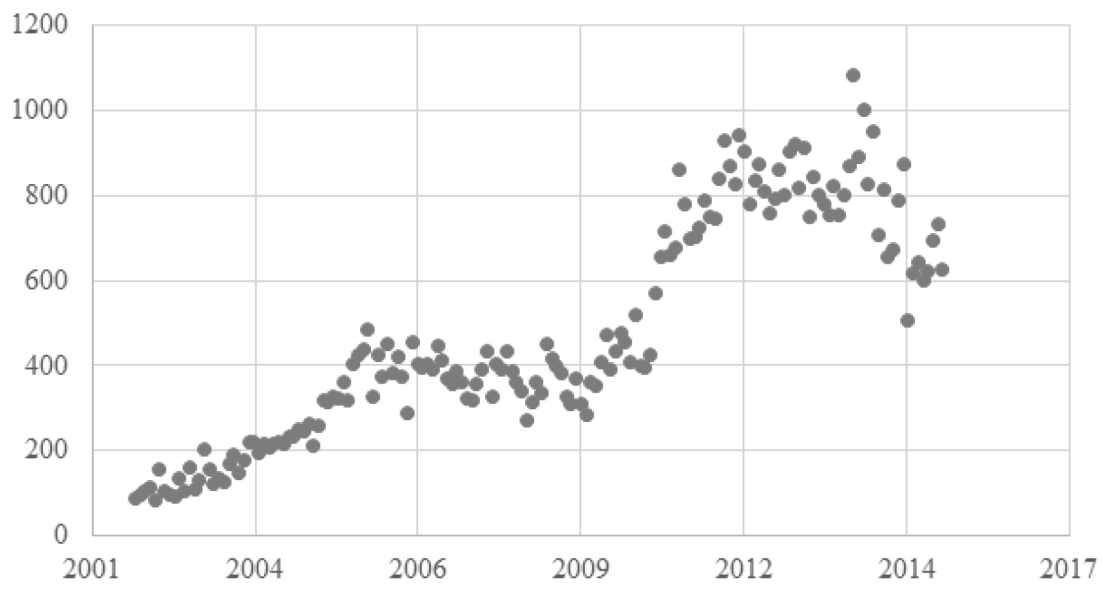

Fig. 2. The number of new AIDS patients

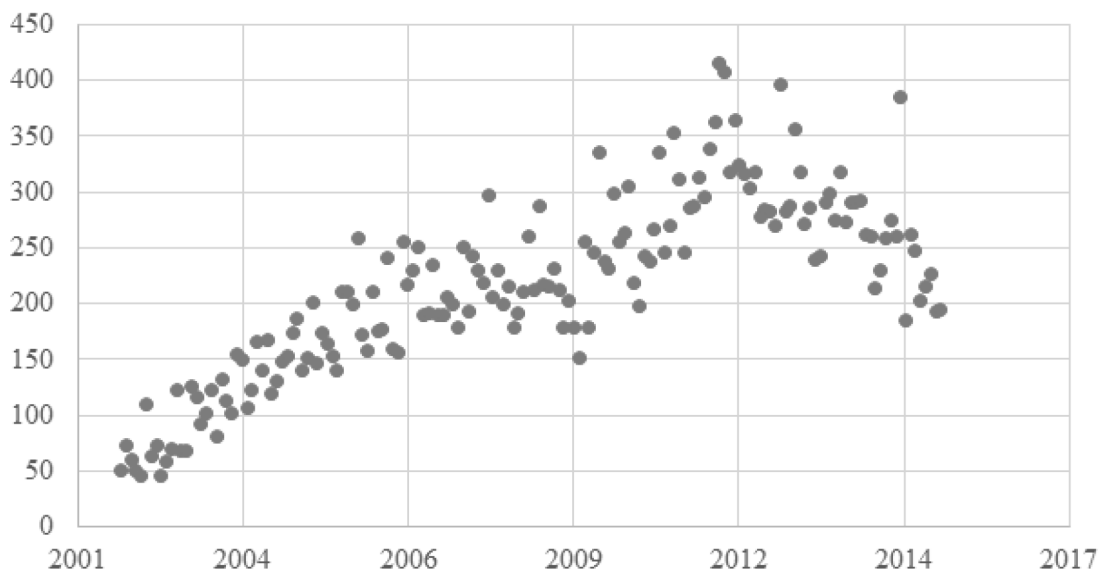

Fig. 3. The number of new AIDS-associated deaths

The aim of this study is to use an SD approach in the modeling of the HIV/AIDS epidemic in Ukraine to estimate its features and trends.

Material and methods. Data source. We used opened statistical data of HIV/AIDS monthly incidence and prevalence in Ukraine [11] also as statistical data of Ukrainian population [12]. Growth of new HIV-infections (HIVnew) between 2001 and 2015 is shown on Fig. 1. With respect to the dynamics of new AIDS cases (AIDSnew), we observed an upward trend with two observed peaks in Fig. 2.

Such peaks suggest low coverage of and/or poor adherence to antiretroviral treatment among HIVinfected persons. As shown in Fig. 3, the number of new AIDS deaths (AIDSdeath_new) has also grown during the same time period with some decrease in the last two years.
Similar growth is observed with exploration of cumulative number of HIV-infections, AIDS cases and AIDS-associated deaths within the same time period and shown in Fig. 4, Fig. 5 and Fig. 6. Also we used dynamic data of Ukrainian population shown in Fig. 7.

System dynamics approach. System dynamics (SD) is a methodology and mathematical modeling technique to frame, understand, and discuss complex issues and problems. Originally developed in the 1950s to help corporate managers improve their understanding of industrial processes, SD is currently being used throughout the public and private sector for policy analysis and design [13]. SD models solve the problem of simultaneity (mutual causation) by updating all variables in small time increments with positive and negative feedbacks and time delays structuring the interactions and control. 


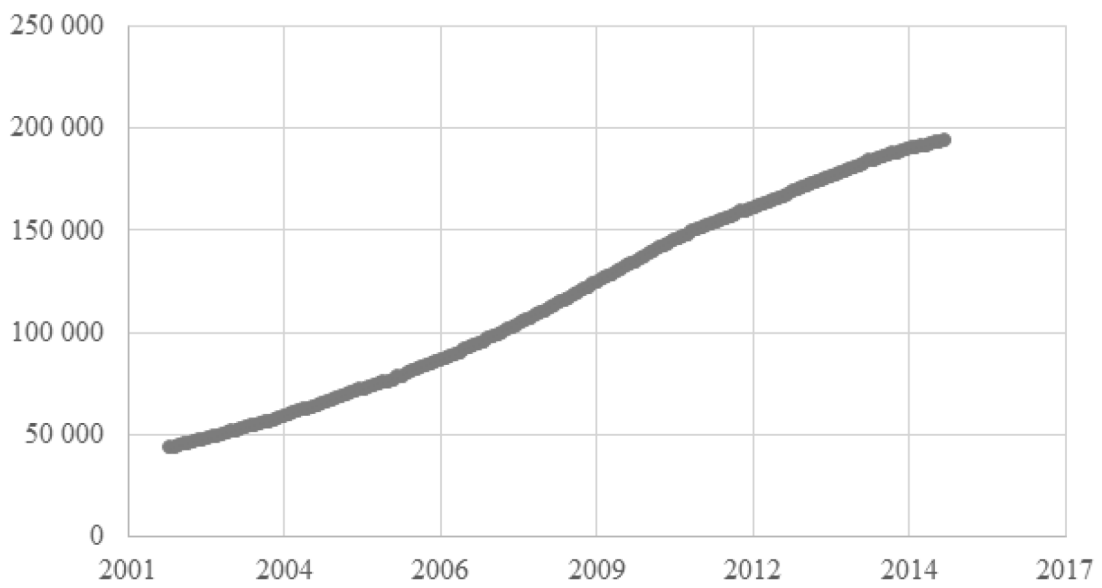

Fig. 4. Cumulative number of HIV-infections

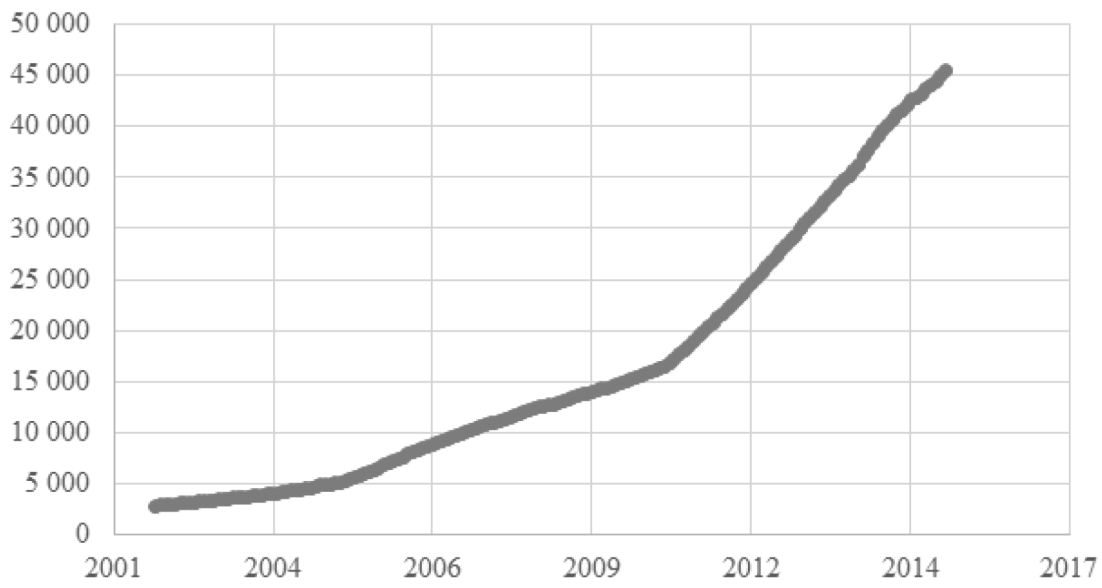

Figure 5. Cumulative number of AIDS cases

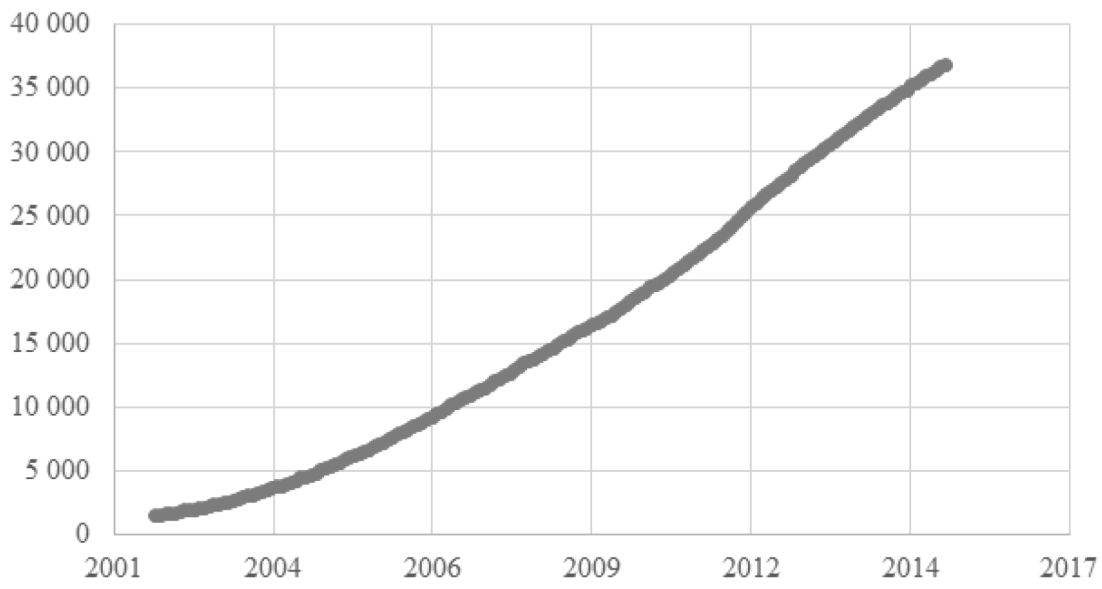

Fig. 6. Cumulative number of AIDS-associated deaths

Results. SD model and its parameterization. compartment (system dynamic) model, widely used As modeling approach, we chose a flow-chart in formal description of infectious disease epidemic 


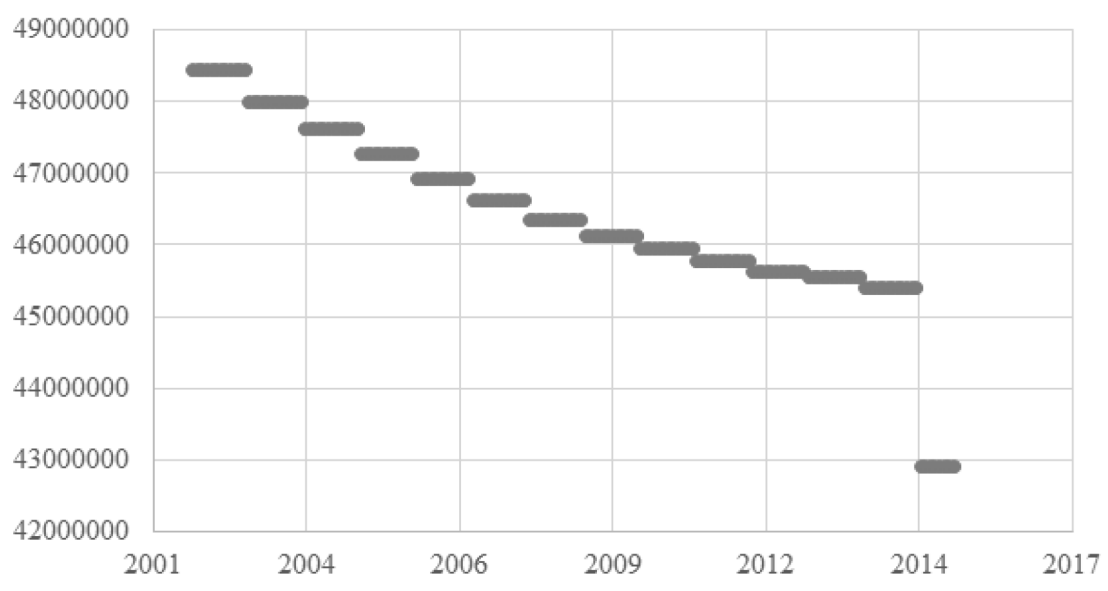

Fig. 7. Cumulative number of all population

process $[14,15]$. The proposed in Fig. 8 model has three compartments, describing three subgroups of Ukrainian population in dynamics: susceptible persons (S), HIV-infected persons (H), patients with AIDS (A). This model, mathematically presented as the system of differential equations (1), is determined with parameters: $\alpha$ - parameter that deter-mines the intensity of population inflow to the system; $\beta$ - transmission parameter of HIV-infection; $\mu$ - rate of progression of HIV to AIDS; $\delta \mathrm{H}$ - mortality rate among HIV-infected persons; $\delta \mathrm{A}-$ mortality rate among patients with AIDS.

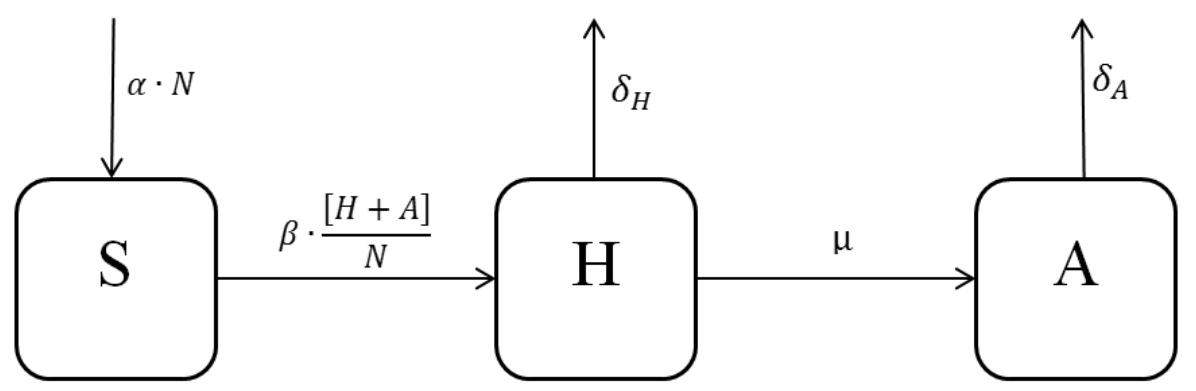

Fig. 8. SD model of HIV/AIDS epidemic in Ukraine

$$
\begin{gathered}
\left\{\begin{array}{l}
\frac{d S}{d t}=\alpha[S+H+A]-\beta \cdot \frac{[H+A]}{N} \cdot S \\
\frac{d H}{d t}=\quad \beta \cdot \frac{[H+A]}{N} \cdot S-\delta_{H} H-\mu H \\
\frac{d A}{d t}=\quad \mu H-\delta_{A} A
\end{array}\right. \\
\beta(t)=\frac{H_{\text {new }}(t) \cdot N(t)}{(H(t)+A(t)) \cdot S(t)}
\end{gathered}
$$

With the use of statistical data described earlier, we have estimated the transition rates between different population subgroups and found that these rates are time-dependent. We estimated that the transmission parameter of HIV-infection in the Ukrainian population, shown in Fig. 9, has been decreasing during decade of years from 0,02 to 0,004 , showing the effectiveness growth of different HIV prevention strategies (condom use, voluntary counseling and testing etc.).

AIDS progression rate (3) has an oscillatory nature in Fig. 10 and varies from 0.002 to 0.006 during the studied years. This could be explained by possible differences in antiretroviral treatment coverage rates of HIV-infected persons, efficiency of antiviral drugs or other available factors.

$$
\mu(t)=\frac{A_{\text {new }}(t)}{H_{\text {all }}(t)}
$$




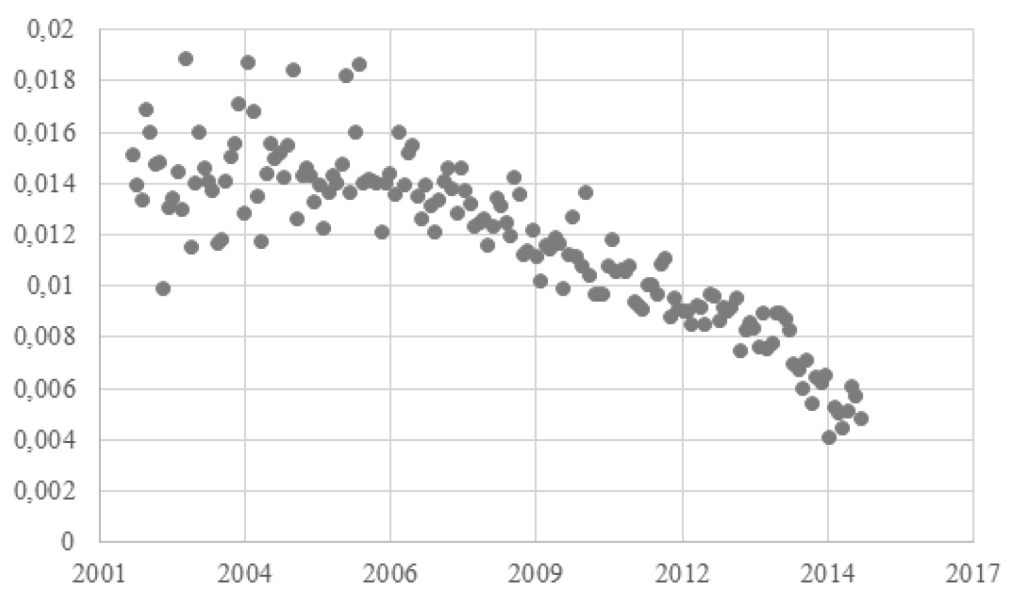

Fig. 9. Transmission parameter of HIV-infection in Ukrainian population

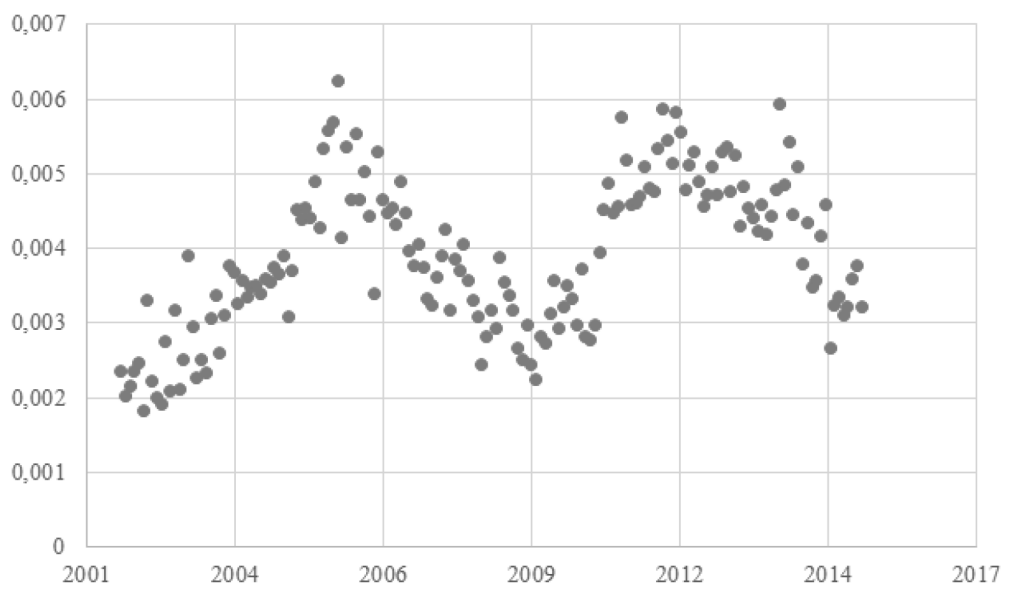

Fig. 10. Rate of HIV-infection progression to AIDS

The death rate of HIV-infected persons (4) was estimated equal to zero during the study period, which could be explained with HIV-infection progression to AIDS and destination of terminal state.

$$
\delta_{H}(t)=\frac{H_{\text {new }}(t)-A_{\text {new }}(t)}{H(t)}
$$

The same oscillatory nature has death rate of AIDSpatients (5) in Fig. 11 decreasing to minimum value $-0,005$.

$$
\delta_{A}(t)=\frac{A_{\text {deat } h \_n e w}(t)}{A(t)}
$$

where $A_{\text {death_new }}(t)$ is new AIDS-associated death cases per month.

We estimated birth rate $(\alpha \cdot \mathrm{N})$ from (1), showing it as negative but increasing trend of parameter of population inflow intensity $\alpha$ in Fig. 12.

$$
S_{t+1}-S_{t}=\alpha N_{t}-H_{\text {new } t}
$$

hence

$$
\alpha N=S_{t+1}-S_{t}+H_{\text {new }}
$$

Dynamic equilibrium points and its stability. One of the main tasks in researching of dynamical systems deals with asymptotic properties of their solutions. The simplest kinds of solution are called equilibrium points (or fixed points). When the system is at equilibrium point it will remain in it. But the behavior of the dynamical system under small perturbation depends on the type of the equilibrium. An equilibrium is stable or asymptotically stable, if system always returns to it after small influence and unstable in other case.

For linear autonomous dynamical systems, type of equilibrium can be determined on eigenvalues of 


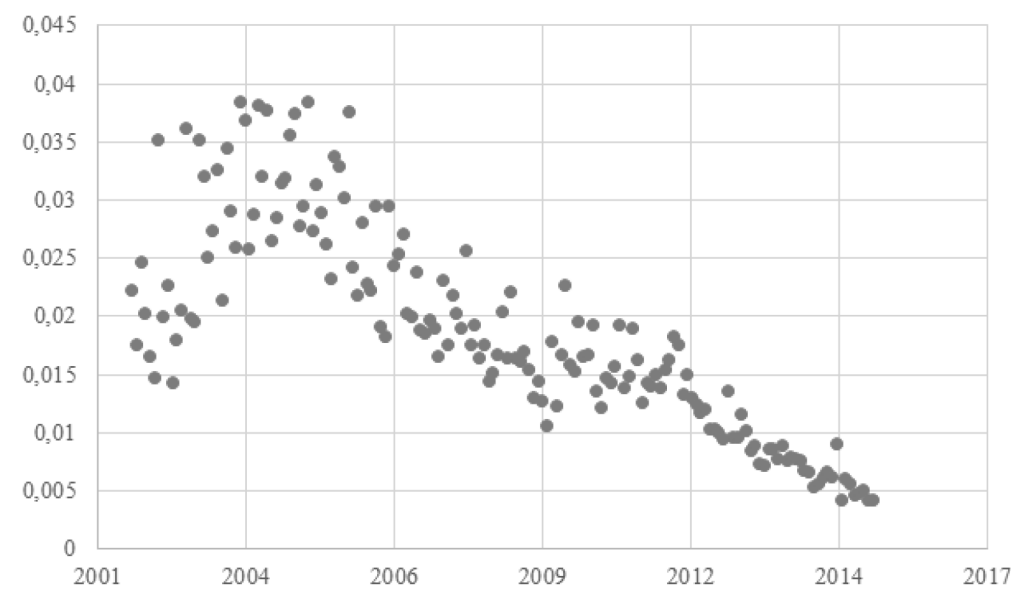

Fig. 11. Rate of HIV-infection progression to AIDS

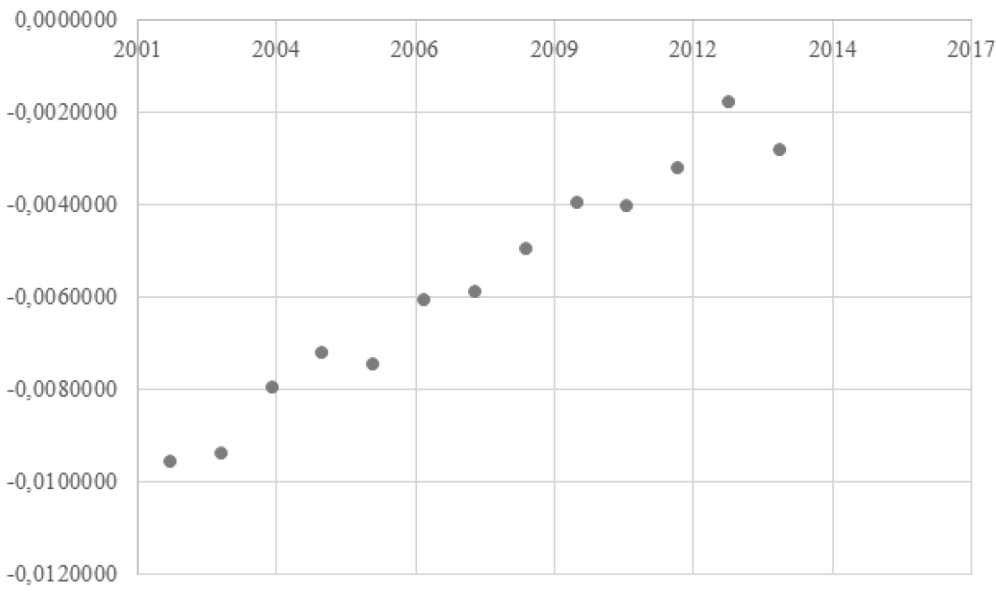

Fig. 12. Parameter of population inflow intensity

matrix of the system. The fixed point is asymptotically stable if and only if all eigenvalues of the matrix have negative real part. If exists some eigenvalue with positive real part then equilibrium is unstable.

If the dynamical system is non-linear then HartmanGrobman theorem can be used in order to determine stability of its fixed points [16]. According to this theorem stability of equilibrium points of non-linear system and its linearization is the same. Matrix of the linearized system is a Jacobian matrix.

So, if all eigenvalues of Jacobian matrix for nonlinear dynamical system have negative real parts then the fixed point will be stable. If at least one eigenvalue has positive real part than the fixed point will be unstable.

Equilibrium of the studied system was obtained equating each differential equation to zero:

$$
\left\{\begin{array}{ccc}
0 & = & \alpha\left[S^{*}+H^{*}+A^{*}\right]-\beta \cdot \frac{\left[H^{*}+A^{*}\right]}{S^{*}+H^{*}+A^{*}} \cdot S^{*} \\
0 & = & \beta \cdot \frac{\left[H^{*}+A^{*}\right]}{S^{*}+H^{*}+A^{*}} \cdot S^{*}-\delta_{H} H^{*}-\mu H^{*} \\
0 & = & \mu H^{*}-\delta_{A} A^{*}
\end{array}\right.
$$

The considered system has two equilibriums: disease-free equilibrium (DFE), when all population is susceptible; and endemic equilibrium (EE), when infectious disease persists in population on constant level.

In order to obtain the characteristic polynomial it is necessary to subtract eigen-values $\lambda$ from the diagonal elements of the Jacobian matrix of the system and calculate the determinant of obtained matrix.

It gave eigenvalues $\lambda 1,2,3$ of different signs in every time point for both equilibria showing it unstable. Results of our estimations of endemic equilibrium 
showed that population fractions would change in time according to Fig. 13.

Therefore, we find that mathematically the studied dynamic system is unstable. Even a small perturbation of dynamic system (change in population, prevention strategies etc.) could lead to a displacement of its equilibrium and commitment to a new equilibrium point, showing the fact that existing level of HIV prevention is not still sufficient to make HIV epidemics in Ukraine stable and controlled.

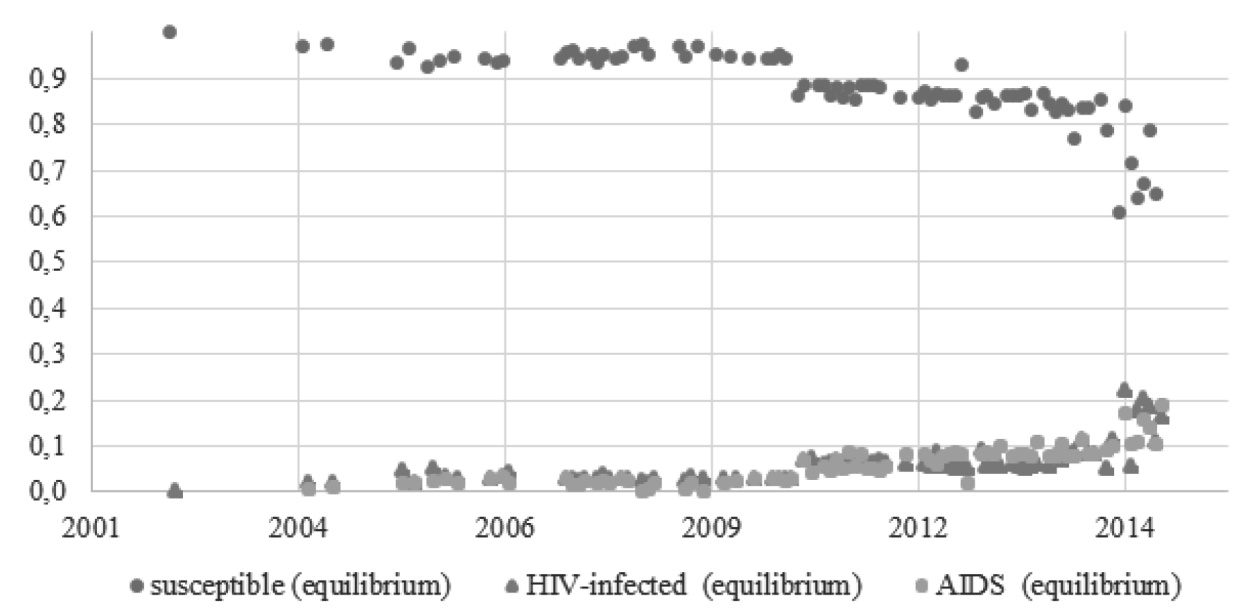

Fig. 13. Equilibrium states

Conclusions and discussion. In the field of HIV prevention, analytic models become necessary for analysis of recent epidemiological data, so simulation of impact of dynamic behavior of HIV prevalence in recent population. In our research, we proposed to consider Ukrainian population as a dynamic system in the context of HIV epidemics. Such dynamic system was divided into three compartments, reflecting susceptible, HIV-infected and AIDS population. We estimated transition rates between these compartments with the use of statistical data that were found time-dependent and characterized dynamics

\section{Література.}

1. Beyrer C. The changing epidemiology of HIV in 2013 / C. Beyrer, Q. Abdool Karim // Curr Opin HIV AIDS. 2013. - № 8 (4). - P. 306-310.

2. UNAIDS, 2016. The Prevention Gap Report. - Режим доступу: http://www.unaids.org/sites/default/files/ media_asset/2016-prevention-gap-report_en.pdf.

3. European Centre for Disease Prevention and Control. HIV/AIDS Surveillance in Europe 2015. - Режим доступу: http://ecdc.europa.eu/en/publications/ Publications/HIV-AIDS-surveillance-Europe-2015.pdf.

4. UCDC. Ukrainian center for Socially Dangerous Disease Control of the Ministry of Health of Ukraine. Operatyvna informaciya. In Ukrainian. 2014. - Режим доступу: http://ucdc.gov.ua/attachments/article/972/\%D0\%A1\%D1\%96\%D1\%87\% D0\%B5\%D0\%BD\%D1\%8C\%202014.pdf. of HIV/AIDS epidemics in Ukraine. We found that key parameters of HIV epidemic process (e.g. HIV transmission parameter) are descending, that reflexes effectiveness of existing prevention strategies such as testing and antiretroviral treatment. Still it will be necessary to estimate the direct influence of existing prevention strategies on HIV epidemic process, functional relationship between such parameters and include it into developed system dynamic model of HIV/AIDS in Ukraine to study its effectiveness that will be the aim of our next studies.

5. Ford A. Modeling the Environment: An Introduction to System Dynamics Modeling of Environmental Systems / A. Ford. - Washington, D.C.: Island Press, 1999.

6. Sterman J. D. Business Dynamics: Systems Thinking and Modelling for a Complex World / J. D. Sterman. Boston: Irwin McGraw-Hill, 2000.

7. Forrester J. W. Principles of Systems / J. W. Forrester. Cambridge, MA: The MIT Press, 1968.

8. Meadows D. L. The Unavoidable A Priori. Elements of the System Dynamics Method / D. L. Meadows. Cambridge, MA: The MIT Press, 1980.

9. Flessa S. Decision support for AIDS control programmes in Eastern Africa / S. Flessa // OR Spectrum. - 2003. № 25. - P. 265. 
10. Dangerfield B. Model based scenarios for the epidemiology of HIV/AIDS: the consequences of highly active antiretroviral therapy / B. Dangerfield, Y. Fang, C. Roberts // System Dynamics Rev. - 2001. - № 17 (2). P. 119-150.

11. Alliance for Public Health - Statistics. In Ukrainian. - Режим доступу: http://aph.org.ua/uk/resursy/ statystyka.

12. Population In Ukraine. - Режим доступу: htttp://www. ukrstat.gov.ua/operativ/operativ2007/ds/nas_rik/nas_u/ nas_rik_u.html.

13. Radzicki M. J. Origin of System Dynamics: Jay W. Forrester and the History of System Dynamics / M. J. Radzicki, R. A. Taylor. - U.S. Department of Energy’s Introduction to System Dynamics, 2008.

14. May R. M. Infectious diseases of humans: dynamics and control / R. M. May, R. M. Anderson. - Oxford: Oxford University Press, 1991.

15. Harko T. Exact analytical solutions of the Susceptible-Infected-Recovered (SIR) epidemic model and of the SIR model with equal death and birth rates / T. Harko, F. S. N. Lobo, M. K. Mak // Applied Mathematics and Computation. - 2014. - № 236. - P. 184-194.

16. Hartmann P. A lemma in the theory of structural stability of differential equations / P. Hartmann // Proc. Amer. Math. Soc. - 1960. - № 11 (4) - P. 610-620.

\section{References.}

1. Beyrer, C., Abdool Karim, Q. (2013). The changing epidemiology of HIV in 2013. Curr Opin HIV AIDS; 8(4), 306-10.

2. UNAIDS (2016). The Prevention Gap Report. URL: http://www.unaids.org/sites/default/files/media_asset/2016-prevention-gap-report_en.pdf. Date of appeal: 12.04.2017.

3. European Centre for Disease Prevention and Control. HIV/AIDS Surveillance in Europe 2015. URL: http:// ecdc.europa.eu/en/publications/Publications/HIVAIDS-surveillance-Europe-2015.pdf. Date of appeal: 12.04.2017.

4. UCDC. Ukrainian center for Socially Dangerous Disease Control of the Ministry of Health of Ukraine. Operatyvna informaciya. In Ukrainian. 2014. URL: http://ucdc. gov.ua/attachments/article/972/\%D0\%A1\%D1\%96\% D1\%87\%D0\%B5\%D0\%BD\%D1\%8C\%202014.pdf. Date of appeal: 12.04.2017.

5. Ford, A. (1999). Modeling the Environment: An Introduction to System Dynamics Modeling of Environmental Systems, Island Press, Washington, D.C.

6. Sterman, J. D. (2000). Business Dynamics: Systems Thinking and Modelling for a Complex World, Irwin McGraw-Hill, Boston.

7. Forrester, J. W. (1968). Principles of Systems, The MIT Press, Cambridge, MA.
8. Meadows, D. L. (1980). The Unavoidable A Priori. Elements of the System Dynamics Method, The MIT Press, Cambridge, MA.

9. Flessa, S. (2003). Decision support for AIDS control programmes in Eastern Africa, OR Spectrum, 25, 265.

10. Dangerfield, B., Fang, Y., Roberts, C. (2001). Model based scenarios for the epidemiology of HIV/AIDS: the consequences of highly active antiretroviral therapy. System Dynamics Rev., 17(2), 119-50.

11. Alliance for Public Health - Statistics. In Ukrainian. URL: http://aph.org.ua/uk/resursy/statystyka. Date of appeal: 12.04.2017.

12. Population In Ukraine. URL: htttp://www.ukrstat.gov. ua/operativ/operativ2007/ds/nas_rik/nas_u/nas_rik_u. html. Date of appeal: 12.04.2017.

13. Radzicki, Michael J., Robert A. Taylor (2008). Origin of System Dynamics: Jay W. Forrester and the History of System Dynamics. In: U.S. Department of Energy's Introduction to System Dynamics.

14. May, Robert M., Anderson, Roy M. (1991). Infectious diseases of humans: dynamics and control, Oxford University Press, Oxford.

15. Harko, T., Lobo, F. S. N., Mak, M. K. (2014). Exact analytical solutions of the Susceptible-Infected-Recovered (SIR) epidemic model and of the SIR model with equal death and birth rates, Applied Mathematics and Computation, 236, 184-94.

16. Hartman, P. (1960). A lemma in the theory of structural stability of differential equations, Proc. Amer .Math. Soc. 11 , no. $4,610-20$. 